\title{
Compositions of partial melts of hydrous pyroxenites in the cratonic mantle lithosphere and their implications for alkaline magma sources
}

\author{
STEPHEN F. FOLEY AND ISRA S EZAD
}

Macquarie University

Presenting Author: stephen.foley@mq.edu.au

Hydrous pyroxenites occur frequently in mantle rocks either as dispersed minerals or discrete rock types. In the cratonic mantle, xenoliths are often assigned to either MARID (mica-amphibolerutile-ilmenite-diopside) or PIC (phlogopite-ilmeniteclinopyroxene), although additional types rich in Ti-oxide minerals occur. Hydrous pyroxenites are commonly hypothesized as source components in alkaline igneous rocks as they are required to explain isotope and trace elements; the major element compositions are poorly constrained.

Here, we present melt compositions from experiments on MARID-like assemblages (phlogopite-clinopyroxene-Krichterite), some with the addition of $5 \%$ ilmenite, rutile or apatite, at 1.5 and 5.0 GPa. A few additional experiments addressed mica clinopyroxenites, which contain Ti-oxides but not the alkali amphibole K-richterite [KR]. Melts were separated into melt traps made of vitreous carbon, facilitating the analysis of large areas of quench-free glass. Reversal and duplicate experiments confirm that equilibrium is achieved for experiments longer than 24 hours and are reproducible between experiments.

Melting of MARIDs begins with the incongruent melting of $\mathrm{K}$-richterite and phlogopite to form $\mathrm{Cpx}$, olivine and melt. $\mathrm{K}$ richterite is melted out at just $50^{\circ} \mathrm{C}$ above the solidus, so that melts are $\mathrm{SiO}_{2}$-rich $(52-56 \mathrm{wt} \%)$ and strongly alkaline $\left(\mathrm{K}_{2} \mathrm{O}>10.5 \mathrm{wt} \%, \mathrm{Na}_{2} \mathrm{O}\right.$ 2.7-4.7 wt $\% ; \mathrm{K}_{2} \mathrm{O} / \mathrm{Na}_{2} \mathrm{O}$ 2.4-5.5). Low $\mathrm{CaO}$ and $\mathrm{Al}_{2} \mathrm{O}_{3}$ contents, together with these alkali contents, declare these melts to be lamproitic ultrapotassic melts. $\mathrm{MgO}$ contents increase with increasing pressure $(8-11 \mathrm{wt} \%$ at $1.5 \mathrm{GPa}$ vs. $16-19$ wt $\%$ at $5 \mathrm{GPa}$ ). Small amounts of accessory phases have large effects on melt compositions, with melts in ilmeniteand rutile-bearing runs containing 6-11 and 11-12 wt\% $\mathrm{TiO}_{2}$ respectively. Experiments with 5\% apatite contain 7-8wt $\%$ $\mathrm{P}_{2} \mathrm{O}_{5}$, are slightly richer in $\mathrm{CaO}$ and $\mathrm{MgO}$, and produce only peritectic Cpx, not olivine. In contrast, partial melts of KR-free mica pyroxenites are richer in $\mathrm{CaO}$ and more akin to kamafugites. The geographically distinctive levels of $\mathrm{TiO}_{2}$ in lamproites around the world can be ascribed to melting of accessory oxide minerals, which are highest in Australian lamproites and lowest in orogenic lamproites and orangeites. Trace elements confirm that accessory oxides and apatite in the source are needed to achieve the enriched patterns of lamproites: $\mathrm{Cpx}+\mathrm{Phl}+\mathrm{KR}$ alone do not produce strongly enriched melts. 